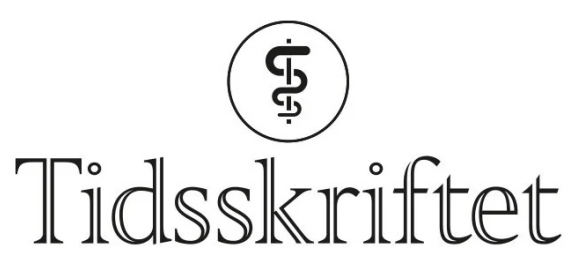

DEN NORSKE LEGEFORENING

\title{
Lærd uten strev
}

MINILEDER

ARE BREAN

Sjefredaktør

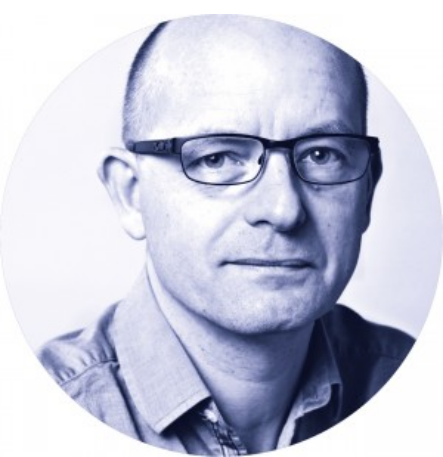

«Tidsskriftet er oppfunnet til lettelse for de som enten er for late eller for opptatte til å lese hele bøker. Det er et middel til å tilfredsstille nysgjerrighet og bli lærd uten å måtte streve.» Dette skrev franskmannen Denis de Sallo (1626-69), som i 1665 grunnla det som har blitt kalt verdens første vitenskapelige tidsskrift, Journal des sçavans.

Norske leger er definitivt ikke late. Men de er opptatte. Derfor har vi også i år satt sammen en rikholdig sommerutgave av Tidsskriftet. Bladet du holder i hånden, inneholder naturlig nok mye om covid-19 - både original norsk forskning og debatt- og lederartikler. Ikke mindre enn tre vitenskapelige artikler om forgiftninger - dessverre et evig sommeraktuelt tema - har fått plass. Det har også en praktisk nyttig oversikt over eksisjon av hudlesjoner, og en interessant originalstudie av samarbeid ved dødsfall i hjemmet. Selvsagt bringer vi som vanlig nyheter fra andre tidsskrifter. I magasin-delen finner du blant mye annet et intervju med president Marit Hermansen og dessuten en sterk og lærerik reportasje. Og i Per Holcks underholdende artikkel om fortidens epidemier kan du lære mer om hvordan tidligere epidemier har blitt håndtert. Med årets sommernummer kan du med andre ord bli enda mer lærd - og det helt uten å streve. Ha en riktig god velfortjent sommerferie!

Publisert: 29. juni 2020. Tidsskr Nor Legeforen. DOI: 10.4045/tidsskr.20.10.01

(C) Tidsskrift for Den norske legeforening 2023. Lastet ned fra tidsskriftet.no 26. april 2023. 